\title{
Sociological Approaches to Leaving Religion
}

\author{
Daniel Enstedt
}

\section{Introducing Sociological Approaches to Leaving Religion}

Sociological research on leaving religion has progressed in four overlapping phases: (1) The initial phase emerged during the 1960 s and focused on the decline in religious affiliation in Western Europe and North America. This research was closely related to studies about secularisation, unbelief, and irreligiosity in modern, Western, and primarily Christian societies. (2) During the 1970 and peaking in the 1980s, studies about the process included exiting not only Christian and Jewish groups, but also new religious movements (henceforth NRMs; so called "cults" or "sects"), and changed the direction of study through discussions of the brainwashing hypothesis and the "snapping" and deprogramming of NRM members. (3) During the third phase, from the $1990 \mathrm{~s}$ until around 2010, research on leaving religion based more on case-studies, but the focus remained on leaving Christianity, Judaism, and NRMs. (4) In the fourth phase, from 2010 on, interest in leaving different religious traditions, such as Islam and orthodox Judaism, grew and was combined with a theoretical development based on empirical fieldwork. The next part of this chapter will discuss the sociological research on leaving religion conducted since the end of the 1960 and onwards.

This chapter fits in a larger framework of secularisation and societal and religious change, but I will limit its scope by focusing on studies that specifically examine the process of leaving religion. ${ }^{1}$ Several different concepts - such as apostasy, deconversion, disaffiliation, religious shifting, "nones" (people who claim no religious affiliation), leave-taking, and becoming an ex - are used in sociological discussions of leaving religion. ${ }^{2}$

1 The boundaries between the sociology of religion and other disciplines, such as psychology, ethnology, and anthropology are not always clear-cut, as some of the research discussed in this chapter will show.

2 See Cragun and Hammer (2011) for a critical discussion of the concepts used in the sociology of religion to examine leaving religion. 
The study of unbelief, irreligiosity, and atheism emerged in the sociology of religion during the 1960s. The papers and discussions from a symposium on unbelief held in Rome in March 1969 were published in The Culture of Unbelief (1971). Peter L. Berger called the symposium "an historic occasion" and a "pioneering venture," and emphasised that the sociology of religion can no longer study religion exclusively, but needs also to "broaden its scope to deal with the social dynamics of contemporary nonreligious culture" (1971: vii-viii). ${ }^{4}$ During the symposium, which highlighted the tension between science and religion, the causes and effects of unbelief were discussed in relation to secularisation, (irreligious) "counterculture," and emerging Marxist theory in modern Western societies. The type of religion emblematic of post-196os America, as outlined by Robert Bellah and Richard Madsen in Habits of the Heart (1985: 221), embraces individualism, anti-authoritarianism, religious bricolage, religious experiences and emotions, self-centeredness, and (not least) disaffiliation from conventional religious groups and established religious organisations and structures. ${ }^{5}$

In Toward a Sociology of Irreligion, Colin Campbell suggested that the debate on secularisation encouraged sociologists to study irreligiosity. "The blunt fact is that until very recently sociologists have entirely ignored irreligion" (Campbell 1971: 8). Furthermore, he warned of a tendency to over-intellectualise the study of irreligiosity: "There is a considerable body of evidence to suggest that the actual transition from religious commitment to religious rejection is much more a matter of moral outrage and ethical rebellion than one of intellectual doubt and rational persuasion" (Campbell 1971: 125). ${ }^{6}$ Robert Bellah addressed a similar problem in The Culture of Unbelief with the term "objectivist fallacy," that is a "sophisticated error in understanding the religious life of the ordinary

3 Parts of the following part have been published elsewhere (see Enstedt 2018).

4 This symposium was attended by Talcott Parsons, Robert Bellah, Thomas Luckmann, Charles Glock, Harvey Cox, Bryan Wilson, and others who have since influenced the sociological study of religion.

5 In Habits of the Heart (1985), sociologists Robert Bellah and Richard Madsen coined the oftcited term "Sheilaism" to cover this type of individual religiosity.

6 Campbell's book had a minor impact, but gained some attention 40 years later when it was republished and more research was conducted in the field of irreligiosity. Lois Lee follows Campbell in Recognizing the Non-Religious (2015) when she scrutinizes secular, non-believing subjectivities in north London. Lee's interest is not primarily on leaving religion but instead on secular and non-believing positions in contemporary society. 
man, which has never been primarily a matter of objectivist belief" (1971: 43). In addition to the objectivist fallacy, one should also consider the overall emphasis on religion and non-religion as "belief" and the neglect of other aspects of (non)religiosity such as practice, habits, emotions, values, and power.

According to Wade Clark Roof, religious defection is part of a larger (counter)cultural trend of criticism and mistrust of institutional religion as part of the established order that guards and reproduces the dominant cultural values and morals of a society (Roof 1978: 44). Roof concluded, based on United States (hereafter US) census data, that religious defection "follows clearly along age, sex, educational, and regional lines. Secular influences in modern society are generally greater among the young, the educated, [...and] men more than woman" (43). Furthermore, "young defectors are prone to come from affluent, middle-class families, and are likely to be married and hold jobs" (Roof 1978: 43). In a survey of Berkeley students, Robert Wuthnow and Charles Y. Glock also concluded that religious defection from "conventional" religion is closely aligned with countercultural behaviour and with "a more general disenchantment with the conventional" and "dissatisfaction with the life that conventional society offers" (Wuthnow and Glock 1973: 175). In a follow-up study, Robert Wuthnow and Glen Mellinger (1978) noted that the tendency to religious defection in the 1960 s and early 1970s had halted, at least among the Berkeley students in their study, but not reversed.

In The Religious Drop-Outs (1977), David Caplovitz and Fred Sherrow aimed to identify the causes of religious apostasy among Jewish, Catholic, and Protestant college students in the US. They suggested that a wider range of various traits could "be seen as questioning either religiosity or the commitment to social groups" (Caplovitz and Sherrow 1977: 182). These conclusions from the 1970s exemplify how leaving religion has been explained and understood in the sociology of religion through the concepts of religious belief (religiosity) and religious belonging (commitment to social groups). "Of all the factors related to apostasy, the most significant, not surprisingly, was religious belief" (Caplovitz and Sherrow 1977: 182). The most "intellectual students" were most likely to question religious articles of faith and to abandon them when they collided with rational arguments. I will return later in the chapter to the questions raised by understanding religion as belief/believing and as belonging.

Caplovitz and Sherrow also pose apostasy "as a form of rebellion against parents" and against the parents' religion (1977: 50). Much of their findings were later criticised by psychologist Bruce Hunsberger: "the assumption that change of religious identification necessarily represents rebellion against parents and rejection of religious identification is, at best, speculation." (Hunsberger 1980: 159; see also Hunsberger 1983, and Altemeyer and Hunsberger 1997). 
One of the earliest attempts to define religious defection is found in Armand L. Mauss's article "Dimensions of Religious Defection" (1969). Mauss noted the lack of research about religious defection, and strove to contribute to the field theoretically by stipulating three dimensions of religious defection: (1) the intellectual (or belief) dimension, (2) the social dimension, and (3), the emotional dimension (1969: 129-139). Combining these three dimensions, a hypothetical eight-celled typology emerges, in which, for example, a person who scores high in all dimensions will be a "total defector," while others can be intellectual or emotional defectors, but still participate regularly in religious activities (Mauss 1969: 131). This typology can help to distinguish various kinds of defection, but it does not explain much about the causes, consequences, and processes of leaving religion. ${ }^{7}$

Merlin B. Brinkerhoff and Kathryn L. Burke (1980) argued for a typology based on the symbolic interactionist perspective, rather than theories about secularisation and demographic factors. Their focus was on leaving "sects," and they concluded that religious "disaffiliation is a gradual, cumulative social process in which negative labeling may act as a "catalyst" accelerating the journey to apostasy while giving it form and direction [...]. Social expectations, consistent with the tag, are communicated to the dissident through interaction." (Brinkerhoff and Burke 1980: $5^{2}$ ). Although leaving religion is still a one-way process, from one position (the believer) to another (the non-believer). As James T. Richardson has pointed out, studies on leaving religion should assume that leaving is not a single event, but rather consider it a "multi-event," that is a more complex, fluid, and sequential process, with no necessary "end station" (Richardson 1978; Richardson 1980). Even so, Richardson continued to view the process as a unidirectional linear process, however complex.

Helen Ebaugh's influential study, Becoming an Ex (1988) must be mentioned in any discussion of the symbolic interactionist perspective on leaving religion. According to Ebaugh, life in modern society is characterised by shifting from role to role. In her analysis of a wide range of different roles during the exit process, Ebaugh (an ex-nun) extracted a set of defined stages passed through before the exit role is internalised. The exit process differs significantly from

7 An elaborated model of the apostasy process is found in Deconversion by Heinz Streib et al. (2009). The authors point out five characteristics of deconversion: "1. Loss of specific religious experiences; 2. intellectual doubt, denial or disagreement with specific beliefs; 3. moral criticism; 4. emotional suffering; 5 . disaffiliation from the community" (Streib et al. 2009: 22). Besides these aspects, they also lists a range of possible "deconversion avenues," or possible outcomes of the deconversion process, such as (1) leaving religion, (2) finding a new religion, or (3) leaving the religious group while keeping some aspects of the religious faith (Streib et al. 2009: 26-28). 
other socialisations into roles, and also differs in type between whether it leads to another major role (as during conversion from one religion to another) or solely to the antithetical exit role. What characterises the exit role in the second case is that the "identity as an ex rests not on one's current role but on who one was in the past" (Ebaugh 1988: 180). While studies on conversion have focused on the process that leads to the new role, studies on deconversion and apostasy focus on the process of leaving a role. "In the process of role exit, there tends to be mutual disengagement in that the individual moves away from the group while the former group simultaneously withdraws from the individual with regard to expectations and social obligations" (Ebaugh 1988: 181-182). The first three stages of exiting a role in this model are (1) doubting, usually because of a change in life situation (for example, unemployment, migration, or change in organisation or relations), (2) seeking alternatives that also reinforce initial doubts, (3) coming to a turning point and its three functions: "the reduction of cognitive dissonance, the opportunity to announce the decision to others, and the mobilisation of the resources needed to exit." (Ebaugh 1988: 184). After the significant turning point, the fourth and last stage consists of creating the exit role that includes a new self-presentation.

Another perspective on leaving religion that gained much attention during the 1980s was aligned with studies of "cults" and the brainwashing hypothesis. But as Stuart A. Wright noted in Leaving Cults: The Dynamics of Defection (1987), the image of the brainwashed cult member was based on popular "misconceptions [that] derive, in part, from accounts by deprogrammed ex-members, anticult organisations, and the resulting images often perpetuated by the media [...]" (Wright 1987: 93). The narrated experiences of critical ex-members became characteristic not only of the general understanding of cults, but also of understandings of religion per se; as an anti-cult organisation quoted by Wright (1987: 94) put it, "All religion is brainwashing." The discourse about "cults" and their strategies of recruiting potential members, frequently reproduced in popular culture and media, has usually been stereotypical and prejudicial. In this discourse, the member is described as a victim, kidnapped or in some way manipulated to join the group. Terms like "mind control" and "brainwashed" are frequently used, and the leader of the religious group is depicted as a pathological individual motivated by money, glory, or sex (Wessinger 2000: 6). The understanding of sect or cult members as victims has been countered by substantial criticism (Richardson and Introvigne 2001: 163).

8 See also Stuart Wright's (1988) "Evaluation of Three Analytical Frameworks on Leaving Religion: Role Theory, Causal Process Model, and Organisational Model." 
Falling from the Faith (1988), edited by David G. Bromley, is divided between discussions of disaffiliation from mainline churches and disaffiliation from NRMS, mainly in an American religious context (Bromley 1988: 9). In the chapter on leaving Mormonism (Church of Latter Day Saints), Albrecht et al. note that religious leave-takers may, may return to the religion they left as young adults or join another church when they are older and about to form a family. One reason given for such a return was the desire to give their children a religious upbringing; another was the feeling of something missing in life. Apostasy was found to be more likely if the original religious socialisation was weak, and a reoccurring sign of immanent apostasy was "a long period of disengagement that preceded disaffiliation" (Albrecht et al. 1988: 79). Religious doctrinal issues are rarely a significant problem that precedes dropping out of religion: "disengagement and disaffiliation are not necessarily accompanied by a rejection of Mormon belief" (Albrecht et al. 1988: 80). ${ }^{9}$ Kirk Hadaway (1989) noted, in line with Albrecht et al., that "it is likely that many of the younger apostates will find their way back to a religious identity." Hadaway conducted a cluster analysis that distinguished between five well-defined subgroups among apostates in the US, ${ }^{10}$ and wrote that "some apostates may reject a religious identity out of consistency with their unbelief, while others may retain belief and even hold a strong religious faith, but reject labeling themselves with the name of a religious institution" (Hadaway 1989: 213).

In the beginning of the 1990s, family formation and gender were analysed in relation to apostasy and religious switching (Sandomirsky and Wilson 1990), different types of religious "careers" (apostates, switchers, converts, and stalwarts), engagement in community, and family (Brinkerhoff and Mackie 1993), and religious mobility such as apostasy and switching on the religious marketplace, where apostasy is a form of cultural consumption restricted by family and organisational variables. In their 1995 article about religious mobility, religious switching, and apostasy, Darren E. Sherkat and John Wilson emphasis the "new paradigm" in the sociology of religion, based on rational choice theory. They complement the focus on the supply side, and the competition between religious institutions and other cultural institution within an open market, by

9 Another aspect of apostasy concerns the apostate's political values, as discussed in Lynn D. Nelson's chapter. Nelson notes that the apostates' political values are liberal in terms of morals and legislation, that "[d]rop-outs are more liberal than the unchurched and church members of all attendance levels," and that "[d]isaffiliation notably increases political liberalism" (Nelson 1988: 133).

10 The subgroups are (1) successful swinging singles, (2) sidetracked singles, (3) young settled liberals, (4) young libertarians, and (5) irreligious traditionalists. 
highlighting the importance of the demand side and the social influence on people's religious choices and preferences (Sherkat and Wilson 1995).

In their Amazing Conversions: Why Some Turn to Faith \& Others Abandon Religion (1997), Bob Altemeyer and Bruce Hunsberger asked about what happens when the predictions made by the socialisation theory fail: when a strong emphasis on religion during childhood leads to apostasy and when a nonreligious upbringing results in religiosity (Altemeyer and Hunsberger 1997: 12). The "amazing" apostates, according to psychologists Altemeyer and Hunsberger, those relatively few who had have an intensive religious upbringing and yet left their parents' or primary caregivers' religion. In contrast, sociologist Matthew T. Loveland concludes his article on religious switching by downplaying religious socialisation, involvement, and education during childhood. Those with a religious upbringing "are no less likely to switch than are those who spent less time learning religious ways of life" (Loveland 2003: 154).

The anthology Leaving Religion and Religious Life (1997), edited by David G. Bromley, William Shaffir and Mordechai Bar-Lev, includes chapters on Canada, the US, Germany, Australia, Israel, and Denmark, and thus somewhat broadens the scope, but the focus remains primarily on Christianity in Western societies, except for two chapters on Judaism. Attempts to contribute theoretically are evident in several of the chapters, emphasising the complex process of leaving religion and its multidimensional outcomes and consequences. Leaving religion in the US is best understood, according to Roof and Landres, more as a "continuing dynamic of religious exit and re-entry than a momentous shift in the religious system as a whole" (Roof and Landres 1997: 94).

The Politics of Religious Apostasy (1998), another volume edited by David G. Bromley, also highlights the role and process of apostasy mainly in relation to Christian groups and NRMs. While one part of the anthology deals with the social construction of the apostate role and the social factors, personal motivations, and individual narratives aligned with it, the other part discusses the role and impact of the apostate in the conflict between NRMs and mainstream society. Interestingly, in this volume emphasis was put on the narratives produced by the apostates, especially in Stuart A. Wright's and Daniel Carson Johnson's chapters. ${ }^{11}$ The anthology Joining and Leaving Religion: Research Perspectives (2000), edited by Francis and Katz, contains not only sociological perspectives on leaving religion, but also educational and theological perspectives. It focuses mainly on Christianity, with some inclusion of Judaism and mention of NRMs. Andrew Yip's chapter on religious leave-taking in non-heterosexual

11 The focus on the narrative aspects of apostasy is highlighted by John D. Barbour in Versions of Deconversion (1994). See Peter Stomberg's chapter in this handbook. 
Christians is particularly interesting in attributing exit in this population not to their loss of faith, but to their wish "to keep their Christian faith intact" (Yip 2000: 142). ${ }^{12}$

In Society without God (2008) and Faith No More (2012), Phil Zuckerman addresses the question of unbelief and apostasy. Society without God examines the "godless" societies of Sweden and Denmark and is based on interviews with nearly 150 Swedes and Danes. Zuckerman gives three theoretical answers for why Sweden and Denmark are so irreligious: "a lazy church monopoly, secure societies, and working women" (Zuckerman 2008: 117). Without competition on a religious market, social and economic deprivation, and someone at home to care for the children's religious upbringing and the family's religiosity, the population becomes more irreligious than before. In Faith No More, Zuckerman turns to the US, examines the experience of leaving religion through in-depth interviews, and finds that in the United States, compared with Scandinavia, "apostasy is more controversial, more deviant, and thus personally more intense and dramatic" (Zuckerman 2012: 171). The reason for this, Zuckerman argues, is that non-religion is the norm in Denmark and Sweden, while the opposite is true in the US. In (Un)believing in Modern Society (2016), Jörg Stolz et al. scrutinise the changing religious landscape in Switzerland from the 1960 until the present day and argue that increased individualisation has led to a "me-society" with a "secular drift" - a tendency to leave institutionalised religion (Stolz et al. 2016: 194). ${ }^{13}$ In contrast to Zuckerman, who mentions religious monopoly as a contributor to secularisation, Stolz et al. claim that religious-secular competition, not religious monopoly, fuels the secular drift (Stolz et al. 2016:11-50).

Simon Cottee's The Apostates (2015) is based on thirty-five life-story interviews with ex-Muslims in Canada and the UK. The process of leaving Islam follows a "coming out of the closet" structure and consists of three phases: before, during, and after apostasy. Cottee describes the phases in detail, ranging from the apostates' changing relationships to food, alcohol, and sex, to what seems to be the hardest part of the process: coming out in front of their religious parents. After leaving their religion, ex-Muslims reported being unable to find a reliable "ex-Muslim post-apostasy script" (Cottee 2015: 173). They described the post-apostasy period as a struggle with their "inner Muslim" and their "halal voice" (Cottee 2015: 176-177). In Becoming Un-Orthodox: Stories of Ex-Hasidic Jews (2015), Lynn Davidman examines the stories of forty ex-Hasidic

\footnotetext{
12 See also Erica Li Lundqvist's chapter in this handbook.

13 Their study is based on life-story interviews with seventy-one people in Switzerland and surveys with 1229 persons in Switzerland.
} 
Jews living in the US. ${ }^{14}$ Her emphasis is not only on narrative, but also embodiment and ritual practices, which have generally been missing in previous studies about leaving religion, and she highlights the process of unlearning and "disinscribing" a religion. Like Cottee, Davidman follows the process of leaving religion, or in this case becoming un-Orthodox, from small first transgressions to overt stepping out. She concludes that "elements of our inbred bodily practices and original cultural tool kits can never be fully abandoned" (Davidman 2015: 195). In When Art Disrupts Religion (2017), Philip S. Francis analyses life stories, memoirs, and field notes from eighty-two Evangelicals to investigate how aesthetic experiences unsettle, undo, and even replace religion. Francis, like Davidman and Cottee, also highlights religious bodily practices, and problematises the one-sided focus on the belief aspect of religion (see also Francis' chapter in this handbook).

\section{3}

\section{Methodological Perspectives and Turning Points}

From the 1960s, a variety of methodological approaches and various kinds of material have been used to develop the sociological study of leaving religion. The most common approaches in the abovementioned research have been formal and informal interviews, collection of observational data, small surveys directed to respondents, and (to a lesser extent) public opinion polls. Previous sociological studies have also tended to be case studies of religious groups such as the Church of Latter Day Saints, the Unitarian Church, and Hasidic Jews, or of specific cohorts such as college students in the US.

Charles Glock suggested, in Culture of Unbelief, that unbelief should be studied by examining first the nature and varieties, and then the causes and effects, of unbelief (Glock 1971). Several sociological studies emphasise the demographic characteristics (education, gender, socioeconomic status, etc.) of those leaving religion. However, an increasing number of studies about the process and various phases of leaving religion have been conducted and have raised questions about the causes and consequences of the process. This development has led to a more nuanced understanding, in which leaving religion is understood as a more fluid and sequential process, with no defined destination. Later in life, leave-takers can even return to the religion they left, for example when they begin to have children and form a family.

14 See Davidman and Greil (2007) for a previous study about exit-narratives of Orthodox Jews. See also Roni Berger's 2014 study about leaving an ultra-Orthodox Jewish community, and Shaffir (1997) for an earlier study about disaffiliates from Jewish group. 
Most sociological studies on people leaving their religion have examined the phenomenon in Christian groups and NRMs, although Judaism has occasionally been included. More recently, there has been a noticeably greater interest in conducting long-term ethnographical fieldwork among other religious traditions, such as Islam, paired with a more theoretically elaborated and critical understanding of the apostasy narrative. One ethical issue that should be considered is the potential risk for researchers to reproduce negative, stereotypical, or even prejudicial images of the religious groups that the apostates have left (see Carter 1998). This risk is evident in studies about the exit process from NRM s, where the discourse about "brainwashing" and manipulative leaders often emerges in apostasy narratives. This is also true for Islam; ex-Muslims' witness narratives are often used in anti-Muslim rhetoric to confirm such an image (Larsson 2016; Enstedt and Larsson 2013).

Previous sociological research has examined the characteristics of religious leave-takers (religious affiliation and upbringing, age, gender, education, and socioeconomic status) and the diverse consequences and outcomes of the apostasy process. The main problems with the prevailing research about leaving religion, as noted by Brinkerhoff and Burke, are that "the process by which the individual disaffiliates [from a religion] has not been systematically examined" and that the prevailing studies provide "rather static pictures of disaffiliation" (Brinkerhoff and Burke 1980: 41). Kirk Hadaway also noted that "[w]e know more about who the apostates are, but we still do not know enough about why people become apostates," and suggested that further research include case studies of apostates and former apostates to "add valuable information to our understanding of the process through which persons reject religion or reaffirm a previously held religious identity" (Hadaway 1989: 214). This critique was repeated in 1997 by William Shaffir wrote that there is only "sparse knowledge about the total process through which individuals disengage and disaffiliate" and that the "long-term consequences flowing from disaffiliation" are not fully understood (1997: 12).

Theories about leaving religion are related to other theories about religious change, often expressed on a personal level. One fundamental distinction needs to be made between disaffiliation as change in religious belief and disaffiliation as a change in religious practice (Yang and Abel 2014: 143). On the one hand, religious belief can remain ostensibly the same, while religious group and group-related practice is abandoned. Hence, a person can leave a religion but still be religious, in what Grace Davie and others have called "believing 
without belonging" (Davie 1994). On the other hand, religious belief can be abandoned, while religious practices, habits, norms and values, which are deeply connected with the religion that has been left, can be kept intact. One can therefore leave the social and belief aspects of religion but still be religious in other aspects (see also Mauss 1969).

The studies by Francis, Davidman, and Cottee mentioned above, show several ways to study leaving religion. Francis' analysis of how aesthetic experiences can unsettle, undo, and even replace religion widens the field by bringing in other materials, and Davidman and Cottee, in their respective studies, discusses the process of leaving religion in relation to bodily practices, and by doing so put the one-sided focus on the belief aspect of religion into question. In addition to these new perspectives and emerging theoretical and methodological developments, it is important to include more religious groups in the study of leaving religion. While more attention has recent been paid to Islam, the lack of research on Hinduism, Buddhism, Shintoism, Sikhism, and Jainism, for example, is evident in this handbook and elsewhere.

Suggestions How to Do It

William Shaffir suggested some future directions in the sociological study of leaving religion, calling for longitudinal studies into the longer consequences of religious leave-taking, and argued for follow-up research into apostates' movements in and out of religion through their lifespans (Shaffir 1997: 12-14). Studying variations in religious change over a lifespan, putting leaving religion in the context of individuals' lives, can help us relate this process to other intrinsic aspects of religiosity, such as teachings, narratives, beliefs, and practices, and extrinsic aspects, such as issues related to religious and family groups, unemployment, migration, health, and economy. Questions about power, gender, and intersectionality should also be addressed more thoroughly. Furthermore, it is also necessary to stress that the question of apostasy is often used as a tool for fighting so-called deviant and competing interpretations and practices within a religious tradition. This is not a new phenomenon, but it has gained a new momentum within for example Islamic traditions, especially after the wars in Syria and Iraq and with the rise of violent interpretations of Islam (Larsson 2017).

Questions could also be asked about how religious groups themselves create apostates, both on an individual level (as examined in most previous research) and on a group level. Such a perspective would focus the century-old sociological question concerning structure and agency on the extent to which 
structural preconditions affect a person leaving religion and ask how far the exit role is already embedded in the structure of the religious community, apostasy narratives, and other expressions of leaving religion. Parts of the left religion -norms, values, and habits - can often still be observed in leave-takers, even if these practices change after exiting the religion: for ex-Muslims, there "is no 'beyond Islam' [...] Islam won't let them go" (Cottee 2015:203; see also Enstedt 2018). A greater focus on everyday life and bodily practices has been suggested to open up the study of leaving religion (McGuire 2008; Ammerman 2014). Studies into areas such as clothing, norms, values, spatiality, theories of multiple religious belonging in a global context, social and emotional factors (Woodhead and Riis 2010), food (Harvey 2015), and materiality (Houtman and Meyer 2012) could all provide valuable insights into the processes, consequences, and even the ambiguity of exiting a religion.

\section{References}

Albrecht, S.L., Cornwall, M., and Cunningham, P.H. 1988. "Leaving New Religious Movements: Issues, Theory, and Research." In D.G. Bromley, ed., Falling from the Faith: Causes and Consequences of Religious Apostasy. Beverly Hills, Calif.: Sage Publications, $62-80$.

Altemeyer, B. and Hunsberger, B. 1997. Amazing Conversions: Why Some Turn to Faith \& Others Abandon Religion. Amherst, N.Y.: Prometheus Books.

Ammerman, N.T. 2014. Sacred Stories, Spiritual Tribes: Finding Religion in Everyday Life. New York: Oxford University Press.

Barbour, J.D. 1994. Versions of Deconversion: Autobiography and the Loss of Faith. Charlottesville: University Press of Virginia.

Bellah, R.N., ed. 1985. Habits of the Heart: Individualism and Commitment in American Life. Berkeley: University of California Press.

Bellah, R., N. 1971. "The Historical Background of Unbelief." In R. Caporale and A. Grumelli, eds., The Culture of Unbelief: Studies and Proceedings from the First International Symposium on Belief, held at Rome, March 22-27, 1969. Berkeley: University of California Press, 39-52.

Berger, P.L. 1971. "Foreword." In R. Caporale and A. Grumelli, eds., The Culture of Unbelief: Studies and Proceedings from the First International Symposium on Belief, held at Rome, March 22-27, 1969. Berkeley: University of California Press, VII-XV.

Berger, R. 2014. "The Journey of Leaving an Insular Community: The Case of UltraOrthodox Jews." The Jewish Journal of Sociology. 56:1-2, 75-98.

Brinkerhoff, M.B., and Burke, K.L. 1980. "Disaffiliation: Some Notes on 'Falling from the Faith.” Sociological Analysis. 41:1, 41-54. 
Brinkerhoff, M.B., and Mackie, M.M. 1993. "Casting off the Bonds of Organized Religion: A Religious-Careers Approach to the Study of Apostasy." Review of Religious Research. 34:3, 235-258.

Bromley, D.G., Shaffir, W., and Bar-Lev, M., eds. 1997. Leaving Religion and Religious Life. Religion and the Social Order. Vol. 7. Greenwich, Connecticut: Jai Press.

Bromley, D.G., ed. 1988. Falling from the Faith: Causes and Consequences of Religious Apostasy. Beverly Hills, California: Sage Publications.

Bromley, D.G. 1988. "Religious Disaffiliation: A Neglected Social Process." In D.G. Bromley, ed. Falling From the Faith: Causes and Consequences of Religious Apostasy. Beverly Hills, California: Sage Publications, 9-25.

Bromley, D.G. ed. 1998. The Politics of Religious Apostasy: The Role of Apostates in the Transformation of Religious Movements. Westport, Connecticut: Praeger.

Campbell, C.D. 1971. Toward a Sociology of Irreligion. London: MacMillan.

Caplovitz, D., and Sherrow, F. 1977. The Religious Drop-outs: Apostasy Among College Graduates. Beverly Hills, California: SAGE.

Carter, L.F. 1998. "Carriers of Tales: On Assessing Credibility of Apostate and Other Outsider Accounts of Religious Practices," in D. G Bromley, ed. The Politics of Religious Apostasy: The Role of Apostates in the Transformation of Religious Movements. Westport, Connecticut: Praeger, 221-238.

Cottee, S. 2015. The Apostates: When Muslims Leave Islam. London: Hurst and Company.

Cragun, R.T., and Hammer, J.H. 2011. “'One Person's Apostate is Another Person's Convert': What Terminology Tells Us about Pro-Religious Hegemony in the Sociology of Religion." Humanity \& Society. 35:1-2, 149-175.

Davidman, L. 2015. Becoming Un-orthodox: Stories of Ex-Hasidic Jews. Oxford and New York: Oxford University Press.

Davidman, L., and Greil, A.L. 2007. "Characters in Search of a Script: The Exit Narratives of Formerly Ultra-Orthodox Jews." Journal for the Scientific Study of Religion. 46:2, 201-216.

Davie, G. 1994. Religion in Britain Since 1945: Believing Without Belonging. Oxford: Blackwell.

Ebaugh, H.R.F. 1988. Becoming an Ex: The Process of Role Exit. Chicago: University of Chicago Press.

Enstedt, D. 2018. "Understanding Religious Apostasy, Disaffiliation and Islam in Contemporary Sweden." In K. van Nieuwkerk, ed., Moving in and Out of Islam, Austin: University of Texas Press, 67-87.

Enstedt, D. and Larsson, G. 2013. "Telling the Truth about Islam? Apostasy Narratives and Representations of Islam on WikiIslam.net." CyberOrient. 7:1.

Francis, L.J., and Katz, Y.J. eds. 200o. Joining and Leaving Religion: Research Perspectives. Leominster: Gracewing.

Francis, P.S. 2017. When Art Disrupts Religion: Aesthetic Experience and the Evangelical Mind. Oxford and New York: Oxford University Press. 
Glock, C.Y. 1971. “The Study of Unbelief: Perspectives on Research.” In R. Caporale and A. Grumelli, eds., The Culture of Unbelief: Studies and Proceedings from the First International Symposium on Belief, held at Rome, March 22-27, 1969. Berkeley: University of California Press, $53^{-76}$.

Hadaway, C.K. 1989. "Identifying American Apostates: A Cluster Analysis." Journal for the Scientific Study of Religion. 28:2, 201-215.

Harvey, G. 2015. "Respectfully Eating or Not Eating. Putting Food at the Centre of Religious Studies." In Religion and Food, Scripta Instituti Donneriani Aboensis, 26, 32-46.

Houtman, D. and Meyer, B. eds. 2012. Things: Religion and the Question of Materiality. New York: Fordham University Press.

Hunsberger, B.E. 1983. "Apostasy: A Social Learning Perspective." Review of Religious Research. 25:1, 21-38.

Hunsberger, B. 1980. "A Reexamination of the Antecedents of Apostasy." Review of Religious Research. 21:2, 158-170.

Larsson G. 2016. “'Most Muslims are Like You and I, but 'Real' Muslims...” Ex-Muslims and Anti-Muslim Sentiments." Journal of Muslims in Europe. 5:2, 205-223.

Larsson, G. 2017. "Apostasy and Counter Narratives - Two Sides of the Same Coin: The Example of the Islamic State." The Review of Faith \& International Affairs. 15:2, 45-54.

Lee, L. 2015. Recognizing the Non-Religious: Reimagining the Secular. Oxford: Oxford University Press.

Loveland, M.T. 2003. "Religious Switching: Preference Development, Maintenance, and Change." Journal for the Scientific Study of Religion. 42:1, 147-157.

Mauss, A.L. 1969. "Dimensions of Religious Defection." Review of Religious Research. 10:3, 128-135.

McGuire, M.B. 2008. Lived Religion: Faith and Practice in Everyday Life. New York: Oxford University Press.

Nelson, L.D. 1988. "Disaffiliation, Desacralization, and Political Values." In David G. Bromley, ed. Falling From the Faith: Causes and Consequences of Religious Apostasy. Beverly Hills, California: Sage Publications, 122-139.

Richardson, J. 1980. “Conversion Careers." Society. 17:3, 47-50.

Richardson, J. ed. 1978. Conversion Careers: In and Out of New Religions. Beverly Hills, California: Sage Publications.

Richardson, J. and Introvigne, M. 2001. "Brainwashing' Theories in European Parliamentary and Administrative Reports on 'Cults' and 'Sects." Journal for the Scientific Study of Religion. 40:2, 143-168.

Riis, O. and Woodhead, L. 2010. A Sociology of Religious Emotion. Oxford: Oxford University Press.

Roof, W.C. and Landres, S.J. 1997. "Defection, Disengagement and Dissent: The Dynamics of Religious Change in the United States." In D.G. Bromley, W. Shaffir, and 
M. Bar-Lev, eds. Leaving Religion and Religious Life. Religion and the Social Order. Vol. 7., Greenwich, Connecticut: Jai Press, 77-96.

Roof, W.C. 1978. "Alienation and Apostasy." Society. 15, 41-45.

Sandomirsky, S. and Wilson, J. 1990. "Processes of Disaffiliation: Religious Mobility among Men and Women." Social Forces. 68:4, 1211-1229.

Shaffir, W. 1997. "Disaffiliation: The Experience of Haredi Jews." In D.G. Bromley, W. Shaffir, and M. Bar-Lev, eds. Leaving Religion and Religious Life. Religion and the Social Order. Vol. 7. Greenwich, Connecticut: Jai Press, 205-228.

Shaffir, W. 1997. “Introduction.” D.G. Bromley, W. Shaffir, and M. Bar-Lev, eds. Leaving Religion and Religious Life. Religion and the Social Order. Vol. 7. Greenwich, Connecticut: Jai Press, 1-16.

Sherkat, D.E. and J. Wilson. 1995. "Preferences, Constraints, and Choices in Religious Markets: An Examination of Religious Switching and Apostasy." Social Forces. 73:3, 993-1026.

Stolz, J. 2016. (Un)believing in Modern Society: Religion, Spirituality, and ReligiousSecular Competition. Abingdon: Routledge.

Streib, H., Hood, R.W., Keller, B., Csöff, R-M., and Silver, C.F. 2009. Deconversion: Qualitative and Quantitative Results from Cross-cultural Research in Germany and the United States of America. Göttingen: Vandenhoeck and Ruprecht.

Wessinger, C.L. 2000. How the Millennium Comes Violently: From Jonestown to Heaven's Gate. New York: Seven Bridges Press.

Wright, S.A. 1988. "Leaving New Religious Movements: Issues, Theory, and Research." In D.G. Bromley, ed. Falling From the Faith: Causes and Consequences of Religious Apostasy. Beverly Hills, California: Sage Publications, 143-165.

Wright, S.A. 1987. Leaving Cults: The Dynamics of Defection. Washington, D.C.: Society for the Scientific Study of Religion.

Wuthnow, R., and Mellinger, G. 1978. "Religious Loyalty, Defection, and Experimentation: A Longitudinal Analysis of University Men." Review of Religious Research. 19(3), 234-245.

Wuthnow, R., and Glock, C.Y. 1973. "Religious Loyalty, Defection, and Experimentation among College Youth." Journal for the Scientific Study of Religion. 12:2, 157-180.

Yip, A.K.T. 200o. "Leaving the Church to Keep my Faith: The Lived Experiences of Nonheterosexual Christians." In L.J. Francis and Y.J. Katz, eds. Joining and Leaving Religion: Research Perspectives. Leominster: Gracewing, 129-145.

Yang, F. and Abel, A. 2014. "Sociology of Religious Conversion." The Oxford Handbook of Religious Conversion. In L.R. Rambo and C.E. Farhadian, eds. Oxford and New York: Oxford University Press, 140-163.

Zuckerman, P. 2012. Faith No More: Why People Reject Religion. Oxford and New York: Oxford University Press.

Zuckerman, P. 2008. Society without God: What the Least Religious Nations can tell us About Contentment. New York: New York University Press. 